\title{
The fluxes and distribution of molybdenum in a mountainous fir forest in two hydrological years
}

\author{
Michopoulos P. ${ }^{1}$, Kostakis M. ${ }^{2}$, Bourletsikas A. ${ }^{1}$, Kaoukis K. ${ }^{1}$, Karetsos G. ${ }^{1}$, Thomaidis N.S. ${ }^{2}$, Nisianakis P. ${ }^{3}$ \\ ${ }^{1}$ H.A.O. DEMETER-Institute of Mediterranean Forest Ecosystems, Terma Alkmanos, Athens 115 28, Greece \\ ${ }^{2}$ Laboratory of Analytical Chemistry, Department of Chemistry, National and Kapodistrian University of Athens, Athens 15771, Greece \\ ${ }^{3}$ Athens Analytical Labs, Chemical Laboratory, El. Venizelou 127, Nea lonia, Athens 14231, Greece \\ Received: 18/10/2019, Accepted: 14/12/2019, Available online: 19/12/2019 \\ *to whom all correspondence should be addressed: e-mail: mipa@fria.gr \\ https://doi.org/10.30955/gnj.003237
}

\section{Abstract}

The distribution, stocks and fluxes of Mo were examined in a mountainous fir forest in Greece in two hydrological years. In both years, the fluxes of Mo in throughfall were lower than those in bulk deposition implying Mo retention and probably uptake by tree canopies. The Mo concentration was appreciable in soil solution but its fluxes were lower than those in throughfall. The Mo fluxes in both bulk and throughfall deposition were higher than those in litterfall, a finding that stresses the importance of the hydrological cycle for this metal. The Mo concentration in the older twigs in the standing trees were higher than the current year ones most probably due to the existence of dry deposition. The concentrations of total Mo in soils reflected the nature of the sedimentary rocks underlying the soil and increased with depth following the clay concentration gradient. The available (oxalate extractable) Mo in soils ranged from $3 \%$ to $14 \%$ of the total Mo. In terms of the stocks of Mo, the soil had by far the highest values in both total and available Mo. The needs of the fir plants for Mo uptake are covered by the available Mo in the mineral soil layers, whereas the Mo content in the organic horizon may not be adequate for this purpose.

Keywords: Molybdenum, fir, deposition, vegetation, litterfall, soil.

\section{Introduction}

Although molybdenum (Mo) is considered a rare trace element, its importance in the global nitrogen $(\mathrm{N})$ cycle is immense. Plants can assimilate nitrates only if the latter is converted to ammonia through its reduction by two separate enzymes: nitrate reductase, which reduces nitrate to nitrite and nitrite reductase, which reduces nitrite to ammonia. The nitrate reductase is a complex enzyme of which an important molecule is Mo (Marschner, 1985).

Perhaps the most prominent role for Mo is as a cofactor in the nitrogenase enzyme in the $\mathrm{N}$ fixation process. Nitrogen fixation is a reaction used by some bacteria to obtain $\mathrm{N}$ from the atmosphere through its conversion to ammonia. The $\mathrm{N}_{2}$ molecule is extremely stable. The industrial production of ammonia requires a temperature of $400{ }^{\circ} \mathrm{C}$ and a pressure of $200-350$ atmospheres. Bacteria are able to carry out this reaction at normal temperature and pressure using the nitrogenase enzyme which consists of two proteins, a large one containing $\mathrm{Fe}$ and $\mathrm{Mo}$ and a small one containing Fe (Wood, 1989). Short supply of Mo can lead to limitation of biological $\mathrm{N}_{2}$ fixation (Silvester, 1989; Jean et al., 2013).

For all these reasons agricultural research has long payed attention to the importance of Mo in the growth and health of both $\mathrm{N}$-fixing and non-fixing crop plants, which has also contributed to the understanding of Mo chemistry in soils (Gupta, 1997; Kaiser et al., 2005).

The important factors that determine Mo availability in soils are $\mathrm{pH}$ and sorption by clay minerals and Fe-Al oxides, a process, which is $\mathrm{pH}$ dependent. At low $\mathrm{pH}$ (3-5) Mo becomes strongly adsorbed (Xu et al., 2013). Recent evidence suggests that Mo can also bind to soil organic matter through ligand exchange and specific adsorption (Wichard, 2009). At high pH, Mo solubility increases with decreased adsorption to the solid soil constituents, which in turn increases Mo loss in leachates as soluble molybdate $\left(\mathrm{MoO}_{4}{ }^{2-}\right)$. The molybdate is the predominant ion form in the soil solution.

In general, the total Mo concentration in mineral soils reflects the nature of parent material. The exception is the organic soil horizons, which can be enriched by Mo in deposition derived from industrial activities. Measuring a core from an ombrotrophic Swiss bog representing $12370{ }^{14} \mathrm{C}$ years of peat accumulation, Krachler and Shotyk (2004) showed that Mo in atmospheric aerosols today is derived mainly from anthropogenic emissions. Nygård et al. (2012) argued that both local point sources and longrange atmospheric transport of pollutants contribute to the enrichment of soil organic horizons with Mo.

As expected, far fewer works have dealt with Mo in forests than in agricultural lands. Tyler (2005) examined 
(among other metals) the concentrations of Mo, in leaves and litterfall of a beech forest. Lang and Kaupenjohann (1999) and Lang and Kaupenjohann (2000) worked with Mo in Norway spruce (needles and soil). Weidner et al. (1996) experimented with the effect of fertilization with Mo on $\mathrm{N}$ contents in needles of Norway spruce, Jean et al. (2013) dealt with the relation of $\mathrm{N}$ fixation with Mo in forest soils and Marks et al. (2015) examined the effect of soil organic matter on storage and mobility of Mo in Douglas fir forests.

So far, the full cycling of Mo in forests has not been examined. The aim of this work is to fill this gap by determining Mo fluxes and distribution in the hydrological cycle, litterfall, vegetation and soil in a forest stand consisting of Bulgarian fir as the main forest species in two hydrological years (2012-2013 and 2013-2014).

\section{Materials and methods}

\subsection{Study area}

The experimental plot is situated in the mountain Timfristos in central Greece, at an altitude of $1170 \mathrm{~m}$. It has an area of 0.27 ha and is enclosed in a catchment of a total area of 147 ha. The average annual rain height is $1433 \mathrm{~mm}$ (average value 1973-2017). The vegetation cover consists of an even aged Bulgarian fir (Abies borisii regis $\mathrm{M}$.) stand in good health having an average age of 100 years approximately. The ground vegetation consists mainly of ferns (Pteridium aquilinum L.), shrubs (Rubus hirtus W. \& K.), herbs (Sanicula europaea L., Geranium lucidum L., Geranium rotundifolium L., Luzula forsteri Sm.) and plants from the family Gramineae such as Melicauniflora R. and Brachypodium sylvaticum $\mathrm{H}$.

The soil was developed on sandy flysch, it is deep and classified as Humic Alisols (FAO, 1988).

\subsection{Experimental set up and sampling}

\subsubsection{Bulk, throughfall deposition and soil solution collection}

In the year 1997, bulk and throughfall deposition collectors were installed in the plot to monitor the quantity and chemistry of precipitation. Bulk deposition was collected with three collectors placed in a forest opening very close to the stand. For throughfall measurements, 30 collectors were placed randomly under the tree canopies in the plot. Details of the deposition collectors' structure are found in the work of Michopoulos et al. (2018). Deposition collection was done weekly and water volume was measured immediately. From the middle of November until the beginning of April funnels and bottles were replaced with plastic bags to collect snow.

Both bulk and througfall deposition formed a pooled sample per month by mixing the weekly samples according to their volume.

Soil solution was collected weekly from July 2009 with zero tension lysimeters at $65 \mathrm{~cm}$ depth. The collection was done in polyethylene bottles placed at the respective depths in soil profiles. There were two repetitions per depth and two replicates per repetition. The samples were pooled according to the volume collected in the bottles and formed one sample per month.

\subsubsection{Soil samples collection}

The soil samples collection was carried out by means of systematic sampling. Inside the plot, along three lines distancing $25 \mathrm{~m}$ from each other six soil pits were excavated. Each pit was five $m$ away from each other. From each soil pit, the samples collected were the $L$ and the $\mathrm{FH}$ horizon by means of a frame $15 \times 15 \mathrm{~cm}$ and mineral soil layers from the depths $0-10 \mathrm{~cm}, 10-20 \mathrm{~cm}$, $20-40 \mathrm{~cm}$ and $40-80 \mathrm{~cm}$. There was mixture of six samples of equal volume per horizon and soil depth to have three pooled samples per horizon and depth. The bulk density of the mineral soils was measured with a cylinder of $129 \mathrm{~cm}^{3}$. The value was converted to bulk density of fine earth after subtracting the volume of coarse material found in the lab. The percentage of large stones was assessed visually in the field.

\subsubsection{Litterfall collection}

For litterfall collection, 10 littertraps in the form of cylindrical plastic buckets, each having a collecting area of $0.242 \mathrm{~m}^{2}$, were placed systematically along a line in the plot, approximately $0.50 \mathrm{~m}$ above ground at a distance of $10 \mathrm{~m}$ from each other. The bottom of each bucket was perforated so that rain or snowmelt water could drain out. A plastic net was put at the bottom of the littertraps to avoid loss of small material. Collection of litterfall was done monthly or for longer periods, depending on the accessibility of the area due to snow. A composite sample was formed and transported to the laboratory for analysis. Needles, twigs, lichens, mosses, insect frass and pollen were separated, dried at $80{ }^{\circ} \mathrm{C}$ for 48 hours and weighed.

\subsubsection{Vegetation sampling and tree measurements}

Needle samples of current and second year from fir trees were from the upper part of the crown from five dominant trees and formed a pooled sample. The three fractions of needles were dried at $80{ }^{\circ} \mathrm{C}$ for 48 hours and weighed.

The ground vegetation was collected in a systematic way by means of a frame having an area of $0.544 \mathrm{~m}^{2}$. The categories collected were: herbs, ferns and grasses. Each category formed a pooled sample, which included both leaves and stems.

Samples of bark and wood were taken from the same trees from which foliage was collected and formed pooled samples.

All the categories of vegetation were dried at $80{ }^{\circ} \mathrm{C}$ for 48 hours and weighed.

The breast diameter and height of all trees were measured in the plot area of 0.273 ha. In total, 86 trees were measured.

\subsubsection{Sampling years}

Bulk deposition, throughfall, soil solution and litterfall were collected for two hydrological years (2012-2013 and 2013-2014). Each hydrological year started on October 1st 
and ended on the 30th of September. Soil samples were collected in the summer of 2007 and vegetation sampling took place in December of 2013. Tree measurements were carried out in October of 2009.

\subsubsection{Sample preparation}

The water (bulk, throughfall deposition and soil solution) samples passed a $0.45 \mu \mathrm{m}$ filter before analysis.

For the determination of $\mathrm{pH}$, texture and available Mo, the $\mathrm{FH}$ and mineral soil samples passed through a $2 \mathrm{~mm}$ sieve. In addition, the samples of the soil $L$ horizon at their initial conditions and those of the $\mathrm{FH}$ horizon and mineral layers after sieving were pulverized in a ball mill for the purpose of total Mo analysis.

The needles and foliar litter were ground in stainless blade mill, whereas the other types of litterfall were pulverized in a ball mill.

\subsection{Chemical analysis}

The soil $\mathrm{pH}$ was measured by a glass electrode in a mixture of soil and water at a ratio of 1:5 per volume. The soil texture was determined by the pipette method. The organic $C$ (in pulverized soil) was determined by a $C$ analyzer.

For the determination of total Mo in soils and vegetation, pulverized soil samples and ground vegetation material were digested in a microwave oven with $\mathrm{HF}$ and aqua regia at a temperature range of $160-170{ }^{\circ} \mathrm{C}$ for $20 \mathrm{~min}$.

Available Mo was extracted from soils with a $0.3 \mathrm{M}$ ammonium oxalate solution (1:10 sieved soil weight to solution volume) at pH 3.3 (Grigg, 1953). Shaking time was $18 \mathrm{~h}$ at $500 \mathrm{rpm}$ on a reciprocal shaker.

Concentrations of Mo in deposition, soil solution, oxalate extracts as well as in soils and plant tissues digests were determined with an ICP-MS instrument (Thermo ICAP QC) using standards commercially available for calibration.

The limit of quantification (LOQ) for Mo in the ICP instrument was calculated for all methods and samples taking into account the limit of detection (three times higher).

\subsection{Calculations}

\subsubsection{Fluxes}

Fluxes of Mo in throughfall, bulk precipitation and soil solution were calculated by multiplying the measured volume in the samplers with the Mo concentrations on a monthly basis and summing the amounts to find the annual flux for each year.

Fluxes of Mo litterfall were calculated by multiplying the concentrations of Mo in the compartment of litterfall with the respective amount of litterfall for each selective period and summing the amounts to find the annual flux for each year.

\subsubsection{Soil and biomass stocks}

The soil stocks of Mo (total and available) up to $80 \mathrm{~m}$ depth (apart from the $L$ horizon) were calculated by multiplying the measured Mo concentrations in each soil layer with layer depth and bulk density of the fine earth
(<2 mm). The volume of large stones, estimated by visual observation, was subtracted from the soil volume used for calculations. The Mo pool in the L horizon was calculated by multiplying its weight by the Mo concentration found.

Allometric equations (Apatsidis and Sifakis, 1999) specific for the silver fir, were applied to estimate the bark and wood volumes of each tree in the year 2009, taking into account trunk diameter and tree height. Branch volume was estimated visually for each tree as a percentage of the trunk tree volume. Stem and branch biomass was calculated by taking into account wood and bark density. In order to calculate the wood and bark density, the volumes of the wood and bark sub-samples were measured by immersing the samples into a volumetric cylinder filled with deionized water. The dry weight of the same samples was found by oven drying at $80^{\circ} \mathrm{C}$ for $48 \mathrm{~h}$.

Live needle biomass was calculated using the allometric equations for mature Silver fir stands reported by Kittredge (1944). These equations use tree diameter and yield the green (fresh) foliage weight. In order to convert the fresh foliage weight to dry weight, sub-samples of needles were selected from the same trees from which leaves were taken for chemical analysis and dried at $80^{\circ} \mathrm{C}$ for $48 \mathrm{~h}$.

Ground vegetation biomass was measured by weighing the biomass collected in the frame used for sampling.

All biomass stocks were calculated by multiplying the measured Mo concentrations by the mass measured. For the needle biomass the Mo concentration used was the average of the concentrations of current and second year needles.

\subsubsection{Statistics}

The Mann-Whitney $U$ Test (an analogous t-test for nonparametric statistics) was applied to compare the Mo concentrations of the two hydrological years in bulk, throughfall and soil solution. This particular test was chosen as it is unknown if the distribution of variances was a normal one. The coefficients of variation for Tables 4 and 5 were calculated as the percentages (\%) of the standard deviation over the means.

\section{Results and discussion}

\subsection{Limits of quantification in the determination of Mo}

The values for the limit of quantification (LQA) for Mo were: $10 \mathrm{ng} \mathrm{L}^{-1}$ for the water samples, $2 \mu \mathrm{g} \mathrm{kg}^{-1}$ for the plant tissue (vegetation), $10 \mathrm{\mu g} \mathrm{kg}^{-1}$ for the total analysis of Mo in soils and $5 \mu \mathrm{g} \mathrm{kg}^{-1}$ for the available Mo (oxalate extractable) in soils. All concentrations values of Mo found in all kind of samples were higher than those mentioned.

\subsection{Hydrological cycle}

In the two hydrological years, the concentrations and fluxes of Mo in throughfall were lower than those in the bulk deposition (Table 1). This means retention of Mo by foliage. A similar result for Mo was found in the hydrological cycle by Campbell et al. (2010) in British Columbia where the bulk and throughfall deposition chemistry were examined in three forest sites having the 
conifer species, Picea (interior hybrid species) and subalpine fir (Abies lasiocarpa, Hook.) and one deciduous paper birch (Betula papyrifera, Marsh). It is not known if forest species can utilize Mo from precipitation just like in the case of nitrogen. So for it has been only a hypothesis which nevertheless should be a subject for further research as there is some evidence from agricultural plants. Incubation of deficient (in Mo) wheat leaf segments in solutions containing Mo markedly increased the activity the nitrate reductase (Randal, 1969).

Table 1 Concentrations and fluxes of Mo in throughfall, bulk deposition and soil solution in the fir plot

\begin{tabular}{|c|c|c|c|}
\hline \multicolumn{4}{|c|}{ Volume weighted means $\left(\mathrm{ng} \mathrm{L}^{-1}\right)$} \\
\hline & $\mathrm{T}$ & B & Soil solution \\
\hline $2012-2013$ & 43.0 & 70.0 & 100 \\
\hline Range & $(11-500)$ & $(10-360)$ & $(40-270)$ \\
\hline 2013-2014 & 186 & 182 & 137 \\
\hline Range & $(20-800)$ & $(20-1200)$ & $(21-509)$ \\
\hline \multicolumn{4}{|c|}{ Fluxes $\left(\mathrm{g} \mathrm{ha}^{-1} \mathrm{yr}^{-1}\right)$} \\
\hline & $\mathrm{T}$ & B & Soil solution \\
\hline 2012-2013 & 0.73 & 1.55 & 0.309 \\
\hline 2013-2014 & 2.66 & 3.24 & 0.322 \\
\hline
\end{tabular}

In terms of the magnitude, the average values of Mo concentration found by the above authors were higher than the ones found in our work but there was great variability in their results. In an older work, Shijo et al. (1996) found similar values with ours in rainwater in Japan (range 13-62 ng L-1). Marks et al. (2015) found lower values of Mo concentration in open precipitation in the Oregon Coast Range in USA (range: 2-20 ng L-1).

There has been no information with regard to Mo concentration in soil solutions derived from zero tension lysimeters in open field. In a glasshouse experiment, Riley et al. (1987) found negligible amounts of Mo in leachates from acidic sandy soils when Mo was added as

Table 2 Concentrations and stocks of Mo in the various components of vegetation

\begin{tabular}{ccc}
\hline Standing trees & Concentrations $\left(\boldsymbol{\mu g} \mathbf{~ k g}^{-1}\right)$ & Stocks $\left._{\mathbf{( g ~ h a}} \mathbf{- 1}\right)$ \\
\hline Current year needles & 46.0 & \\
\hline Second year needles & 47.0 & 9.52 \\
\hline All needles & 47.0 & 0.014 \\
\hline Current year twigs & 30.0 & 1.61 \\
\hline Older twigs & 152 & 6.74 \\
\hline Trunk & 27.0 & 0.782 \\
\hline Trunk bark & 27.0 & 0.381 \\
\hline Branches & 20.0 & Total = 19.0 \\
\hline Ground vegetation & & \\
\hline Herbs & & 0.048 \\
\hline Ferns & 176 & 0.007 \\
\hline Grasses & 114 & 0.0005 \\
\hline
\end{tabular}

Na-molybdate. Rutkowska et al. (2017) found an average of $282 \mathrm{ng} \mathrm{L}^{-1}$ in the most common agricultural soils in Poland using a vacuum pump. In our work, the Mo concentration range in the two hydrological years was somewhat lower (100-137 ng L $\mathrm{L}^{-1}$ ) (Table 1). This was to be expected as in our work the soil solution was subjected only to gravity forces and not to suction.

The Mann-Whitney $U$ test did not show any significant difference with regard to Mo concentrations between the two hydrological years for the bulk, throughfall and soil solution. Maybe more years are required to find significant trends (if any) in the hydrological cycle.

The fact that FH horizon has higher concentrations of Mo than those in foliar litterfall (Tables $3 \& 5$ ), leads to the conclusions that the $\mathrm{FH}$ layer is enriched by the Mo content in the throuhgfall deposition. Marks et al. (2015) reached the same conclusions dealing with the above-mentioned forest (Douglas fir) in the Oregon Coast Range in USA.

The budget of the hydrochemical fluxes of Mo (throughfall - soil solution) were positive entailing Mo retention from soils. It is not known which part of soils retained the most of Mo. Both organic matter and Fe and Al oxides have this capacity. Well-drained sandy soils have been shown to leach significant amounts of Mo unless the $\mathrm{pH}$ is low (Jones and Belling, 1967). The $\mathrm{pH}$ of the soil in the fir stand is not acidic and one would expect that the hydrochemical budget of Mo would not be positive. As the $\mathrm{C}$ content becomes lower further down the soil profile, the responsible soil components for Mo absorption are mainly the clay content and the oxides of Fe and Al. This will be shown in the data of the total and the extracted Mo with ammonium oxalate.

\subsection{Vegetation}

So far, there has not been any information on Mo concentrations in fir needles in literature. For this reason, we compared the Mo needle content in our work (Table 2) with that in Norway spruce (Lang and Kaupenjohann, 2000). Despite the fact that the two species are conifers, the comparisons should be made with caution. The concentrations of Mo in the current and second year needles in our work were above the deficiency level of $40 \mu \mathrm{gg}^{-1}$ reported to bring about Mo deficiency in Norway spruce (Lang and Kaupenjohann, 2000). The above-mentioned authors found a range of 
5 to $48 \mu \mathrm{g} \mathrm{kg}^{-1}$ Mo concentrations for current year needles in Norway spruce in Germany. In our work, the concentrations of Mo in the first and second year needles were close to the higher values. When comparing Mo concentrations, one has to take into account the tree age. Indeed, age seems to play a significant role in the Mo content in needles. Weidner et al. (1996) found $150 \mu \mathrm{g} \mathrm{kg}^{-1} \mathrm{Mo}$ in current year needles of a 12 year Norway spruce stand supposed to suffer from Mo deficiency. Lang and Kaupenjohann (1999) found $100 \mu \mathrm{g}$ $\mathrm{kg}^{-1}$ in the current year needles of a 20 year old Norway spruce stand. It seems that young trees have a high uptake of Mo. The fir stand in our work is a mature one and the Mo concentrations in needles probably reflect its age.

Old twigs had higher concentrations of Mo than younger ones (Table 2). As twigs have a rougher surface than needles, we can conclude that dry deposition affected the Mo concentrations in the older twig. The same process took place in litterfall as explained below.

The trunk and trunk bark had lower concentrations of Mo than in the needles (Table 2), which were nevertheless detectable unlike $\mathrm{Cr}$ and $\mathrm{As}$ that were below the detection limit in that vegetation fraction of the same fir stand (Michopoulos et al., 2018). Trunk wood accumulates elements mainly from the soil and its metal concentration does not reflect the atmospheric deposition (Rossini Oliva and Mingorance, 2006). So there is uptake of Mo from the soil.

In the ground vegetation, the herbs (followed by the ferns) had the highest concentrations of Mo (Table 2), higher than the current and second year needles. It is possible that their surface is rougher than that in current and second year needles.

\subsection{Litterfall}

The concentrations of Mo in foliar litterfall are higher than the current and second year needles (Tables $2 \& 3$ ). Tyler et al. (2005) found the same results in a beech forest in Sweden when they compared Mo concentrations in beach leaves and litterfall. As the foliar litterfall mainly consists of older needles, the dry deposition plays a significant role in the enrichment as mentioned above. The non-foliar litterfall has a higher concentration of Mo than the foliar one (Table 3). This is due to the plenty exchange sites in that kind of litterfall consisting of twigs, lichens, mosses and insect frass. The range of the Mo concentration is very high in both types of litterfall reflecting the variability of Mo content in dry deposition. The fluxes of Mo in litterfall are higher than in the Douglas fir litterfall in the Oregon Coast Range in USA (Marks et al., 2015) which has been, so far, the only piece of information with regard to Mo in forest litterfall. This difference can be a species or a climate effect.

\subsection{Soils}

The average total concentration of Mo in the earth crust is $1500 \mathrm{\mu g} \mathrm{kg}^{-1}$ (Das et al., 2007) but in the soils, it is somewhat higher (2300 $\mathrm{\mu g} \mathrm{kg}^{-1}$, Fortescue, 1992). The soil in the fir stand plot had concentrations similar to that in the earth crust (Table 5). Marks et al. (2015) found a little higher concentrations of total Mo in the $0-10 \mathrm{~cm}$ soil layer overlying sedimentary rocks (average $1200 \mathrm{\mu g} \mathrm{kg}^{-1}$ ) than the corresponding concentration in the same soil layer in the fir plot.

Table 3 Concentrations and fluxes of Mo in foliar and non-foliar litterfall in the fir plot

\begin{tabular}{|c|c|c|}
\hline & Foliar & Non foliar \\
\hline \multicolumn{3}{|c|}{ Concentrations $\left(\mu \mathrm{g} \mathrm{kg}^{-1}\right)$} \\
\hline 2012-2013 Range & $143(23.0-645)$ & $218(181-290)$ \\
\hline 2013-2014 Range & $123(17.0-260)$ & $304(46.0-649)$ \\
\hline \multicolumn{3}{|c|}{ Fluxes $\left(\mathrm{g} \mathrm{ha}^{-1} \mathrm{yr}^{-1}\right)$} \\
\hline 2012-2013 & 0.497 & 0.327 \\
\hline $2013-2014$ & 0.380 & 0.409 \\
\hline
\end{tabular}

The percentage (\%) of available Mo with regard to the total Mo ranged from $3.4 \%$ in the $\mathrm{FH}$ layer to $14.4 \%$ in the 20-40 cm mineral layer. Duval et al. (2015) found far lower percentages of the oxalate extractable Mo in coastal Florida spodosols $(0.32-0.42 \%)$. These soils were very acidic. Our results in absolute amounts $\left(\mu \mathrm{g} \mathrm{kg}^{-1}\right)$ resemble those of Cambisols in Germany (Lang and Kaupenjohann, 2000). It must be pointed out that the use of ammonium oxalate (still widely used) to extract available Mo has been criticized by some researchers (Griggs, 1960; Burmester et al., 1988) on the grounds that it extracts some Mo unavailable to plants. In any case, Lombin (1985) found a significant correlation between Mo concentrations in legumes and ammonium oxalate extractable Mo when the soil organic matter was also taken into account as independent variable. In this work the purpose of including the data from oxalate extractable Mo was not prediction but comparisons with the findings by other researchers.

Table 4 Values of selected properties of soils. Organic $\mathrm{C}$ and clay are expressed in percentages (\%).

\begin{tabular}{|c|c|c|c|}
\hline Layer & $\mathrm{pH}$ & Org. C & Clay \\
\hline \multirow[t]{2}{*}{$\mathrm{FH}$} & 6.48 & 23.0 & \\
\hline & $(0.24)^{*}$ & (13) & \\
\hline \multirow[t]{2}{*}{$0-10 \mathrm{~cm}$} & 6.07 & 5.12 & 27.2 \\
\hline & $(1.99)$ & $(20.0)$ & $(2.02)$ \\
\hline \multirow[t]{2}{*}{$10-20 \mathrm{~cm}$} & 5.77 & 3.36 & 31.2 \\
\hline & $(3.15)$ & $(10.3)$ & $(2.1)$ \\
\hline \multirow[t]{2}{*}{$20-40 \mathrm{~cm}$} & 5.54 & 2.75 & 33.0 \\
\hline & $(1.18)$ & $(3.51)$ & (6.7) \\
\hline \multirow[t]{2}{*}{$40-80 \mathrm{~cm}$} & 5.32 & 1.53 & 34.9 \\
\hline & (1.49) & (19.3) & (14.1) \\
\hline
\end{tabular}

*Coefficient of variation

It is interesting that the coefficients of variations in the concentrations of available Mo were found consistently higher than the ones in the total Mo.There is one possible explanation for this discrepancy. The labile Mo probably depends on plant uptake, which in turn depends on the plants rooting system structure. The latter is not uniform in space and therefore the Mo content is affected. This conclusion is close to the one reached by Lang and 
Kaupenjohann (2000) who stated that Mo turnover within forest ecosystems was governed by Mo plant availability of mineral soils as well as by plant Mo uptake.

Another remark is that the contents of both total and available Mo increase gradually further down the soil profile (Table 5). As the organic C content becomes lower with depth (Table 4), the concentration gradients of total and oxalate extractable Mo follow that of clay. Similarly, Lombin (1985) found a significant correlation between oxalate extractable Mo and clay content in soils low in organic matter in Nigeria. The clay fraction can include clay minerals as well as Fe and Al oxides. In this work, there is no discrimination between the metal oxides and clay minerals.

\subsection{Stocks of Mo in the fir ecosystem}

With respect to the vegetation stocks (Table 2 ), the foliage and trunk had the highest stocks because of their large mass. The needles had about the $50 \%$ of the Mo stock in the standing vegetation. There is a reservation here. The stock of Mo in needles was calculated according to the values of the current and second year needles, which were almost the same (Table 2). It was a presupposition that the rest of the needles (older than two years) had the same concentrations. According to Lang and Kaupenjohann (2000), the old needles of conifers contain less Mo than the younger ones. In this work, the older than two years needles were not analyzed for Mo.

Table 5 Concentrations and stocks of total and available Mo in soils
Therefore, the calculated stock of Mo in the canopy probably represents the highest value.

The ground vegetation did not contribute much in terms of the Mo stock (Table 2). It must be pointed, however, that the turnover rate of the ground vegetation is much faster than the tree trunk and trunk bark so its role should not be underestimated.

The stocks of Mo in soils were by far the highest (Table 5). Trees have to replenish the amounts nutrients lost in litterfall both in above and belowground (Cole and Rapp, 1981). The percentages of available Mo, especially in the mineral soil $(0-10 \mathrm{~cm}$ layer and below) can fully cover the Mo fluxes lost by the aboveground litterfall. The available amount of Mo in the FH layer may not be enough for the plant needs if the aboveground litterfall (Table 3) plus the belowground one (not measured in this work) exceeds the $2 \mathrm{~g} \mathrm{ha}^{-1} \mathrm{yr}^{-1}$. We can conclude therefore, that the mineral soil, in terms of quantity, is more important in supplying Mo to forest trees than the $\mathrm{FH}$ horizon. It is worth noting that Grigg (1953) categorized responsive soils to fertilizers as those containing oxalate extractable Mo less than $200 \mu \mathrm{g} \mathrm{kg}$. In our work, all the concentrations of oxalate extractable Mo are lower than that value (Table 5). However, in forest plants, as mentioned above, it is the stock of available nutrients in soils capable of covering the plant nutrient needs and not a fixed concentration value.

\begin{tabular}{ccccc}
\hline \multirow{2}{*}{ Layer } & \multicolumn{2}{c}{ Concentrations $\left(\boldsymbol{\mu g} \mathbf{~ k g}^{-1}\right)$} & \multicolumn{2}{c}{ Stocks $\left(\mathbf{g ~ h a} \mathbf{~}^{-1}\right)$} \\
\cline { 2 - 5 } & Total & Available & Total & Available \\
\hline $\mathrm{L}$ & $96.0(92)^{*}$ & & 0.941 & 56.8 \\
\hline $\mathrm{FH}$ & $711(14)$ & $24.0(34)$ & 568 & 44.7 \\
\hline $0-10 \mathrm{~cm}$ & $916(8.8)$ & $71.9(26)$ & 997 & 92.0 \\
\hline $10-20 \mathrm{~cm}$ & $1170(16)$ & $108(24)$ & 2088 & 301 \\
\hline $20-40 \mathrm{~cm}$ & $1290(9.4)$ & $186(39)$ & 2849 & 342 \\
\hline $40-80 \mathrm{~cm}$ & $1470(16)$ & $176(32)$ & & \\
\hline
\end{tabular}

*Coefficient of variation

\section{Conclusions}

The hydrological cycle of Mo may be more important than originally thought in providing forest species with Mo. This becomes evident from the higher Mo fluxes in bulk and throughfall deposition than litterfall, the retention of Mo in the forest canopy and the positive hydrochemical flux. The higher Mo concentrations in older twigs in the fir trees implies dry deposition of this metal. The first mineral soil layer contains enough available Mo (extracted with ammonium oxalate) to replenish the Mo lost in litterfall.

\section{Acknowledgements}

The authors express their appreciation to the Ministry of Agriculture and Food, the Mistry of Environment and the European Commission, which financially sustain the Programme of "Effects of Atmospheric Pollutants on Forest Ecosystems" on the framework of which the current project was based. In addition, the authors want to express their sincere thanks to Dr E. Daskalakou for her contribution to measuring tree heights and diameters as well as to Mrs. Ch. Mitropoulou for her help with sample pretreatment and analysis. Finally, the authors express their gratitude to the Forest Service of Karpenisi for their invaluable practical assistance with all the problems encountered.

\section{References}

Apatsidis L. and Sifakis H. (1999), Electronic applications for the calculation of static and dynamic elements of forest stands of beech, fir, oak, spruce, Black pine, Aleppo pine, Scotch pine and cypress, Forest Research Institute of Athens Publishers, Athens, Greece (in Greek).

Burmester C.H., Adams J.F. and Odom J.W. (1988), Response of soybean to lime and molybdenum on ultisols in northern Alabama, Soil Science Society American Journal, 52, 1391-1394.

Campbell J., Bradfield G.E., Prescott C.E. and Fredeen L. (2010), The influence of overstorey Populus on epiphytic lichens in sub boreal spruce forests of British Columbia, Canadian Journal of Forest Research, 40, 143-154.

Cole D.W. and Rapp M. (1981), Elemental cycling in forest ecosystems, In: Dynamic properties of forest ecosystems, Reichle D.E. (Eds.). London: Cambridge University Press. 
Das A.K., Charaborty R., Cervera M.L. and Guardia M. (2007), A review on molybdenum determination in solid geological samples, Talanta, 71, 987-1000.

Duval B.D., Natali S.M. and Hungate B.A. (2015), What constitutes plant-available molybdenum in sandy acidic soils? Communications in Soil Science and Plant Analysis, 46, 318-326.

FAO-Unesco (1988), Soil map of the world, Rome, Italy: FAOUnesco.

Fortescue J.A.C. (1992), Landscape geochemistry: retrospect and prospect, Applied Geochemistry, 7, 1-53.

Grigg J.L. (1953), Determination of the available molybdenum of soils, New Zealand Journal of Science and Technology 34, 405-414.

Grigg J.L. (1960), The distribution of molybdenum in soils of New Zealand. I. Soils of the North Island, New Zealand Journal of Agricultural Research, 3, 69-86.

Gupta U.C. (1997), Molybdenum in agriculture, New York: Cambridge University Press.

Jean M.E., Phayvong K., Forest-Drolet J. and Bellenger J.P. (2013), Molybdenum and phosphorus limitation of asymbiotic nitrogen fixation in forests of Eastern Canada: influence of vegetative cover and seasonal variability, Soil Biology and Biochemistry, 67, 140-146.

Jones G.B. and Belling G.B. (1967), The movement of coper, molybdenum, and selenium in soils as indicated by radioactive isotopes, Australian Journal of Agricultural Research, 18, 733-740.

Kaiser B.N., Gridley K.L., Brady J.N., Phillips T. and Tyerman S.D. (2005), The role of molybdenum in agricultural plant production, Annals of Botany, 96, 745-754.

Krachler M. and Shotyk W. (2004), Natural and anthropogenic enrichments of molybdenum, thorium, and uranium in a complete peat bog profile, Jura Mountains, Switzerland, Journal of Environmental Monitoring, 6, 418-426.

Kittredge J. (1944), Estimation of the amount of foliage of trees and stands, Journal of Forestry, 42, 905-912.

Lang F. and Kaupenjohann M. (1999), Molybdenum fractions and mobilization kinetics in acid forest soils, Journal of Plant Nutrition and Soil Science, 162, 309-314.

Lang F. and Kaupenjohann M. (2000), Molybdenum at German Norway spruce sites: contents and mobility, Canadian Journal of Forest Research, 30, 1034-1040.

Lombin G. (1985), Evaluation of the Micronutrient Fertility of Nigeria's Semi-Arid Savannah Soils: Boron and Molybdenum, Soil Science and Plant Nutrition, 31, 13-25.

Marks J.A., Perakis S.S., King E.K. and Pett-Ridge J. (2015), Soil organic matter regulates molybdenum storage and mobility in forests, Biogeochemistry, 125, 167-183.

Marschner H. (1985), Mineral nutrition of higher plants, London: Academic Press.

Michopoulos P., Bourletsikas A., Kaoukis K., Daskalakou E., Karetsos G., Kostakis M., Thomaidis N.S., Pasias I.N., Kaberi H. and Iliakis S. (2018), The distribution and variability of heavy metals in a mountainous fir forest ecosystem in two hydrological years, Global NEST Journal, 20, 188-197.

Nygård T., Steinnes E. and Røyset O. (2012), Distribution of 32 Elements in Organic Surface Soils: Contributions from Atmospheric Transport of Pollutants and Natural Source, Water Air and Soil Pollution, 223, 699-713.
Randal P.J. (1969), Changes in nitrate and nitrate reductase levels on restoration of molybdenum to molybdenumdeficient plants, Australian Journal of Agricultural Research 20, 635-642.

Riley M.M., Robson A.D., Gartrell J.W. and Jeffrey R.C. (1987), The absence of leaching of molybdenum in acid soils from Western Australia, Australian Journal of Soil Research, 25, 179-184.

Rosssini Oliva S. and Mingorance M.D. (2006), Assessment of airborne heavy metal pollution by aboveground pant parts, Chemosphere 65, 177-182.

Rutkowska B., Szulc W., Spychaj-Fabisiak E. and Pior N. (2017), Prediction of molybdenum availability to plants in differentiated soil conditions. Plant Soil and Environment, 63, 491-497.

Shijo Y., Suzuki M., Shimizu T. and Aratake S. (1996), Determination of trace amounts of molybdenum in rainwater and snow by graphite-furnace absorption spectrometry after solvent extraction and micro-volume back-extraction, Analytical Sciences, 12, 953-957

Silvester W.B. (1989), Molybdenum limitation of asymbiotic nitrogen fixation in forests of Pacific Northwest America, Soil Biology and Biochemistry, 21, 283-289.

Tyler G. (2005), Changes in the concentrations of major, minor and rare-earth elements during leaf senescence and decomposition in a Fagus sylvatica forest, Forest Ecology and Management, 206, 167-177.

Weidner M., Brückner H., Pajak E., Schmidt B. and Wichtmann H. (1996), Differential effects of potassium and molybdenum deficiency and fertilization on nitrogen metabolism in Norway spruce, Zeitschrift Pflanzenernähr und Bodenkunde, 159, 199-206.

Wichard T., Mishra B., Myneni S.C.B., Bellenger J.P. and Kraepiel A.M.L. (2009), Storage and bioavailability Of Molybdenum in soils increased by organic matter complexation, Nature Geoscience 2, 625-629.

Wood M. (1989), Soil Biology, New York: Blackie.

Xu N., Braida W., Christodoulatos C. and Chen J. (2013), A review of molybdenum adsorption in soils/bed sediments: speciation, mechanism, and model applications, Soil and Sediments Contamination, 22, 912-929. 